\title{
The Christian Roots of the Philanthropic Concept of Social Work Helena Machulová
}

\begin{abstract}
The article deals with the Christian roots of contemporary social work. Using the example of the classical Christian conception of acts of mercy, it shows that the basis of Christian help to one's neighbour is a proper understanding of the human person and his place in society. It also points to the similarities and differences of contemporary social work and Christian charity work.
\end{abstract}

\section{Keywords}

mercy, philanthropic concept of social work, Christian charity

\section{Introduction}

Social work as an independent discipline began to establish itself at the turn of the $20^{\text {th }}$ century. ${ }^{1}$ However, it cannot be said that it originated without a background. It is usually stated that it follows the rich tradition of Christian charity, or love for one's neighbour. ${ }^{2}$ Today, both Christian charity work and social work stand side by side. Are they more or less the same or are they different? Is their action directed in the same direction, towards the same goal? Can they inspire one another?

The aim of this article is to present the reasons for supporting the thesis on the continuity and connection between Christian charity and contemporary social work. The specific procedure of the article is as follows: (1) the presentation of the concept of man as a prerequisite and starting point for Christian charity; (2) an examination of works of mercy, that is, the practical realisation of love (caritas) for one's neighbour in the work of Thomas Aquinas, which represents a well-formulated and reasoned summary of the traditional Christian concept of charity; and (3) the search for interfaces between the Christian concept of works of mercy and today's philanthropically oriented social work.

\section{Personality}

The most important point, as well as the starting point, for the concept of Christian charity is the concept of man as a person because it tries to capture the complex nature of the human being. On the one hand, man is perceived as the pinnacle of all creation, as a faithful image of God, the

1 Cf. Oldřich MATOUŠEK and Jakub DOLEŽEL, Sociální práce v době současné, in: Encyklopedie sociální práce, ed. Oldřich Matoušek et al., Praha: Portál, 2013, p. 189.

2 Cf. Ctirad V. POSPÍŠIL, Teologie služby, Kostelní Vydř́i: Karmelitánské nakladatelství, 2002, pp. 69-136. 
only being among all creatures that is capable of acting freely and thus responsibly. It is precisely this ability, to act responsibly, from which human dignity is derived. Man is a creature capable of a personal relationship with God and his neighbours, and is aware of his dependence on the Creator. On the other hand, the concept does not forget the sin of man and his ability to fail in fulfilling his mission. This failure does not have to remain only on a personal level. It also affects and violates human social relations. Another important feature of a human person is his ability to perceive transcendence. It can be perceived both in a horizontal sense when a person transcends the horizon of his self, emerges from himself, and relates to other people. This experience of relationship has a formative character for man, and it can be said that, in order to become truly oneself, one must come out of and forget about oneself.

We all participate in the same human nature, share the bond of human coexistence, and we are all similar to God's image because our being comes from the same Source. This is why we are aware of a certain affinity with other people, as if they were a kind of 'complement' to our limited being. The perception of one's own transcendence also has a vertical level where one comes out of oneself to God. In this case, one stops focusing on oneself, on his own development, and focuses his attention away from himself, to the Source of everything. He no longer focuses on his own good and the good of his loved ones as he rather focuses on the Good as such. The point of view is therefore changing because one does not look at everything from his own perspective only but also from God's perspective. Paradoxically, however, this leads him again to a deeper look at himself and to a deeper love for himself and others. Every coming out of oneself, whether horizontal or vertical, leads one to a deeper understanding of himself and a fuller realisation of one's own being. ${ }^{3}$ Man is always searching for the fulfilment of his existence but he realises that he will not attain his completion in the earthly existence. He perceives the open future of his life which he can shape but which remains uncertain. Our being cannot be perfectly fulfilled in time, neither the individual being nor the being of the whole society. It is therefore impossible to create a definitive and equitable world order. The Christian concept of such an arrangement of the world cannot be fully realised in earthly life. ${ }^{4}$

An equally important aspect of human existence is the physical and mental unity of the human person - each person is the body in which the human spirit is expressed. One cannot be separated from the other. Man and other animals are part of material nature but man, unlike animals, is not limited to material nature. He lives in the awareness of his own rational subjectivity. ${ }^{5}$ Thus, when a Christian sees a person in need of help, he perceives both the greatness and the imperfection of that person, and is aware of his own greatness and imperfection. We are all equal in this, even though each of us shows it in our own unique way. The whole topic of the concept of the human person can be further developed theologically but that would go beyond the scope of this text. So let us move on and look at the place of man in society. Although each person is a unique human person, it is not possible to develop and live independently without the company of other people. The Christian concept of man is therefore personalistic. In this form, it avoids the extremes of individualist liberalism (which negates the intrinsically social nature of man) on the one hand and reductive collectivism (which reduces man to a mere part of society and thereby disturbs his true individuality) on the other. It understands a human person as a unique and independent being but, at the same time, it perceives his connection with others. Man is fully human in communion

Cf. William N. CLARKE, Osoba a bytí, Praha: Krystal OP, 2007, pp. 98-111.

Cf. Bernhard SUTOR, Politická etika, Praha: OIKOYMENH, 1996, pp. 21-24.

Cf. Arno ANZENBACHER, Krestanská sociální etika, Brno: CDK, 2004, pp. 179-184. 
with others that he needs. Both uniqueness and relationship inherently belong to the human person and one cannot develop without the other. The formation of each person's unique personality is precisely in social relationships. ${ }^{6}$ We are not born in the form of completely finished persons. We shape our personality through our inclusion in certain social relationships; on the other hand, the social side does not arise by itself as it is formed by relationships between individual persons. Therefore, it is necessary to perceive both well and avoid the reduction of the human person only to his individual side, as individualism does; also, it is not good to succumb to the opposite error offered by collectivism, that is, to overestimate the social side and to claim that man is only a product of society. ${ }^{7}$

This humanistic conception of man is the basis of a proper understanding of love which is not a mere friendship (filia), nor erotic affection (eros), nor affinity (storge). It is a completely free and selfless desire and a manifestation of good towards the neighbour (agape). ${ }^{8}$ And this love, for which the word caritas is used in Latin language, is the starting point for deeds done for the neighbour. Such love is called charity.

\section{Love and Mercy}

The connection between love and practical manifestations of the care of one's neighbour, as understood in Christianity, can be well illustrated by the doctrine of Thomas Aquinas, who is one of the most striking figures of the Christian intellectual tradition. He puts forward ideas that are currently in social work in the treatise on alms which is today usually associated only with money or something that can be expressed with money. Such an understanding, though, is too narrow for a medieval author. Let us now look at the medieval concept of alms in more detail. According to Thomas, this is 'an act of love through mercy.' ${ }^{\text {' }}$ To gain a better picture of what Thomas has in mind, we need to clarify how he understands love and mercy. Today's understanding of these terms may be somewhat different. Therefore, it is important to understand the meaning of these terms in that classical theological text. The word love can be understood in several different meanings. As already mentioned, Greek or Latin has different words for individual meanings, while Czech has to be satisfied with just one. In Thomas's text, therefore, there is the theological virtue of love (Greek agapé, Latin caritas). In addition to this love, there are other kinds of love, such as erotic, friendly, or family. How to distinguish between these different kinds of love? The first and fundamental distinction is whether love is an emotional reaction to any good or whether love is an act of will. The former is a spontaneous and natural expression of affection for the recognised good. An example of this love is erotic or kinship love. The latter is more a manifestation of reason and will. The divine virtue of love (caritas) is an example of such love. ${ }^{10}$

One of the manifestations of this love is mercy, which can be understood as compassion for a neighbour who is in need. Therefore, someone has mercy when he feels sadness or pain from another's misfortune. ${ }^{11}$ This compassion for one's neighbour means some solidarity with the one who experiences the problem. Such solidarity is accompanied by a tendency to somehow help

6 The social doctrine of the Church represents personalism as one of its main principles. Cf. Kompendium sociální nauky církve, Kostelní Vydří: Karmelitánské nakladatelství, 2008, pp. 81-111.

7 Cf. SUTOR, Politická etika..., pp. 24-29.

8 Cf. Benedikt XVI., Deus caritas est, Praha: Paulínky, 2006, pp. 7-16.

9 Thomas AQUINAS, ST II-II, q. 32, a. 1 (The texts from the Theological Sum of Thomas Aquinas are cited in a standard way, i.e., by the part (Roman numeral), the question number (q. as quaestio) and the article number (a. as articulus)).

10 Cf. Josef PIEPER, O víre. O naději. O lásce, Praha: Krystal OP, 2018, pp. 120-124.

11 Cf. AQUINAS, ST II-II, q. 30. 
him. This compassion can exist in man on two levels. On the one hand, it is a manifestation of the senses on the level of emotions, and, on the other hand, it is reasoning manifesting itself in the form of will. And just when reason controls and directs that emotional plane, we can speak of virtue. Virtue is a rationally controlled habit aimed at cultivating human abilities. So, Thomas understands mercy not as love itself but as a virtue that comes from love. It is the ability to express love effectively. The specific manifestations of mercy which is understood in this way may have, among other things, the form of alms. We can add that such mercy comes with Christianity. In history, we may encounter another understanding of mercy. For Aristotle, mercy is one of the passions. Therefore, he leaves it only on an emotional level and does not add rationality. The fact that bad people have a good life and good people live in bad conditions makes him sad. This sadness is then strongly linked to a certain awareness. One realises that the situation which happened to his fellow men can also happen to him. The degree of mercy is therefore greatly influenced by the fact of whether we are at risk of similar unhappiness or evil. For the Stoics, mercy remains a passion, and therefore it is something unwanted or dangerous. Their ideal is a passion-free person. For them, a state of soul equilibrium (the centre between two extremes) is desirable. In our case, one extreme is strictness which can become cruel and the other is kindness which can degenerate into mercy. However, this does not mean that helping the other is unacceptable to the stoic. It must only be guided by the balance of the soul, not by compassion. Similarly, mercy is undesirable for Nietzsche, though for another reason. He sees mercy as a trait of a lower man who cannot enforce his will. Moreover, the manifestations of mercy keep alive those who are not worthy. Nietzsche thus condemns not only mercy but also loses any personalistic perspective. In his thinking, the other ceases to be a person and becomes only a competitor. ${ }^{12}$

\section{Thomas' Concept of the Works of Mercy}

Now we come to Thomas's conception of the works of mercy, which one can find in detail and see clearly elaborated in the part of the Summa Theologica focusing on the theological virtue of love (caritas), more precisely in the treatise on 'acts of love through mercy. ${ }^{13}$ Here, Thomas continues the old tradition of distinguishing many of the shortcomings ${ }^{14}$ that may be troubling for our fellow men and to which one must respond with the right kind of mercy. The classical concept says that there are seven bodily deeds (feed the hungry, water the thirsty, dress the naked, receive a guest, visit the sick, ransom captives, bury the dead) and seven spiritual deeds (teach the uneducated, advise the doubtful, comfort the sad, admonish the sinner, forgive the offender, endure the difficult and inconvenient, and pray for all). These shortcomings of our fellow men may be both physical and spiritual so that both types of these shortcomings can be responded to by the corresponding act of mercy. Thomas further systematises and divides all deficiencies in order to include all levels of the human person - not only the physical but also the emotional and spiritual side.

The physical problems, according to Thomas, can exist either during life or after life. What a person lacks in life can be both the basic things needed for living and the special needs arising from an accident. Thomas then divides the general shortcomings into internal and external. The inner deficiency may be hunger or thirst, and it is therefore necessary to feed the hungry, and to give water to the thirsty. The external deficiency then relates to clothing or dwellings. The classic kind of mercy

12 Cf. Tomáš MACHULA, Význam milosrdenství pro pojetí člověka, Salve 1/2015, pp. 13-21.

13 AQUINAS, ST II-II, q. 32, a. 1.

14 We translate the Latin term defectus here as a deficiency, meaning any difficulties, problems, illnesses, difficult situations, etc. 
in this area is to dress the naked and to receive a guest. The same applies to special difficulties. These also arise, according to Thomas, from internal causes such as illness where it is necessary to visit the sick, or external causes which include the ransoming of captives. ${ }^{15}$ The mercy that belongs to the dead is the funeral. ${ }^{16}$ Human life should be properly completed not only mentally and spiritually, but also physically. This means a sensible and respectful treatment of the body of the deceased. At the physical level, therefore, it is taking care of both basic human needs and specific situations where a person finds himself for some reason during his life in a problem and this complicates his living in various ways and even prevents the fulfilment of basic needs (illness or various types of disabilities, loss of dwelling, loss of freedom, etc.). Here it is appropriate to consider the situation and offer an adequate act of mercy, i.e., the help that is most needed.

Deficiencies in the spiritual area are addressed in two ways. On the one hand, it is a request for the help of God (a prayer $)^{17}$ and, on the other, concrete human help. Thomas also divides this according to various kinds of deficiencies. If one's neighbour lacks something in the area of theoretical reason (when it comes to the truth, or how things are) then it is appropriate to help him by giving information. ${ }^{18}$ When there is a lack of practical reason (when it comes to knowing the right behaviour, that is, how we should behave) some advice ${ }^{19}$ can help. Other shortcomings may be emotional, the greatest of which is sadness. One can give comfort ${ }^{20}$ to his neighbour in order to eliminate this. The last shortcoming in the spiritual area is what manifests itself in one's bad actions. This problem can be seen from three perspectives. Speaking about the originator of such an act, admonition ${ }^{21}$ may help him. Furthermore, we can see such a deed in the perspective of the victim - if it is against us, we can help by forgiving ${ }^{22}$ the insult. We can also look at these deeds in terms of their consequences. Here, tolerance can help, that is, if one tolerates the weaknesses of his fellow men. ${ }^{23}$ This applies in particular to those who are close to such a person, and his bad behaviour affects them even if the person did not intend to do so. ${ }^{24}$ Here, Thomas shows very well how to distinguish between the level of knowledge, emotions, and deeds, and how to respond adequately to each of these kinds of difficulties. In some cases, there should be concrete help; in other cases, there should be the realisation that not everything can be changed and that there are shortcomings that we need to endure. Then, perhaps, our fellow men will be similarly patient with our shortcomings.

This text of Thomas, however, is not a mere 'guide' on how to help a neighbour in need. We can find much more in it. As a brilliant theologian and philosopher, Thomas made a great contribution to defining the Christian concept of the human person. This includes the very understanding of the

15 All these merciful deeds are summarised in Jesus' parable: 'Then the King will say to those on his right, "Come, you who are blessed by my Father; take your inheritance, the kingdom prepared for you since the creation of the world. For I was hungry and you gave me something to eat, I was thirsty and you gave me something to drink, I was a stranger and you invited me in, I needed clothes and you clothed me, I was sick and you looked after me, I was in prison and you came to visit me."' (Mathew 25:34-36). Here and below, we cite examples of biblical places where this mercy is mentioned.

16 An example of this act of mercy is in the Old Testament, in the Book of Tobit, as shown in Tobit 2.

17 'And pray in the Spirit on all occasions with all kinds of prayers and requests. With this in mind, be alert and always keep on praying for all the Lord's people.' (Ephesians 6:18).

18 'But in the church I would rather speak five intelligible words to instruct others than ten thousand words in a tongue.' (1 Corinthians 14:19).

19 'Never do anything without thinking it through, and once you have done something, don't look back and wish you had done something else.' (Sirach 32:19).

20 'If we are distressed, it is for your comfort and salvation; if we are comforted, it is for your comfort, which produces in you patient endurance of the same sufferings we suffer.' (2 Corinthians 1:6).

21 'He is the one we proclaim, admonishing and teaching everyone with all wisdom, so that we may present everyone fully mature in Christ.' (Colossians 1:28).

22 'And when you stand praying, if you hold anything against anyone, forgive them, so that your Father in heaven may forgive you your sins.' (Mark 11:25).

23 'We who are strong ought to bear with the failings of the weak and not to please ourselves.' (Romans 15:1).

24 Cf. AQUINAS, ST II-II q. 32, a. 1-2. 
human person, his place in society, and the specific concept of love for one's neighbour. A proper understanding of each of these aspects then forms the Christian concept of helping others. In later times, Christian social teaching has been formulated on these foundations. The main principles of this teaching are personality, solidarity, and subsidiarity. ${ }^{25}$

\section{From Individual Charity to Institutionalised Social Work}

Solidarity with the suffering and serving these people is one of the typical expressions of Christian spirituality. Its root and source is God's love for man which leads him to love not only God but also his neighbour. It was Jesus who showed solidarity with the suffering person who needed help in both physical and spiritual terms. In many parts of the New Testament we read that he was moved by compassion when seeing the suffering of others. ${ }^{26}$ In connection with the actions of Jesus, the early Church continued to be charitable. Seven deacons were in charge of charity and serving. ${ }^{27}$ Charitable work has been present in the Church since its inception to this day. Gradually, charitable work has developed, not only with the activities of individuals, but a number of institutes or hospitals, and also whole religious communities whose main mission was charitable activities (for example, the Order of Lazarists took care of lepers, the Knights Hospitaller or the German Knights took care of the sick). In the time of the Enlightenment there were efforts to better organise Christian charity and its theoretical anchoring. In addition, the role of the state in the social field was increasing. ${ }^{28}$ Gradually, secular social work started to separate from Christian charity and both worked side by side. In both areas there was a more theoretical reflection of the practice itself and its better organisation. The burning social issues were reflected in the social doctrine of the Church, in the first encyclical by Leo XIII Rerum novarum, which was published in $1891 .^{29}$ Similarly, at the turn of the $20^{\text {th }}$ century, the first education in the profession of social work started to form itself and its theoretical base began to be built. It was based mainly on the use of theories and concepts of other social science disciplines. This is one of the reasons why the theoretical basis of social work is still the subject of major discussions. The presentation of these, however, would go beyond the scope of this text. ${ }^{30}$

So, it can be said that today's social work continues the rich tradition of Christian charity. It is also developing further today, although the concrete form of solidarity with those suffering is changing as society is changing and new problems and difficulties for people are emerging. What remains unchanged is the starting point and goal of Christian charity. It is still a reflection of God's love for man and a desire to help those who really need it.

\section{Bio-psycho-socio-spiritual Dimension of Man}

The above presented conception of the works of mercy, where mercy is a manifestation of love (caritas), is a possible starting point for comparing the traditional Christian understanding of mercy (including its practical forms) with contemporary social work. Today's social work is a theoretical and practical discipline based on the knowledge of many other disciplines (psychology,

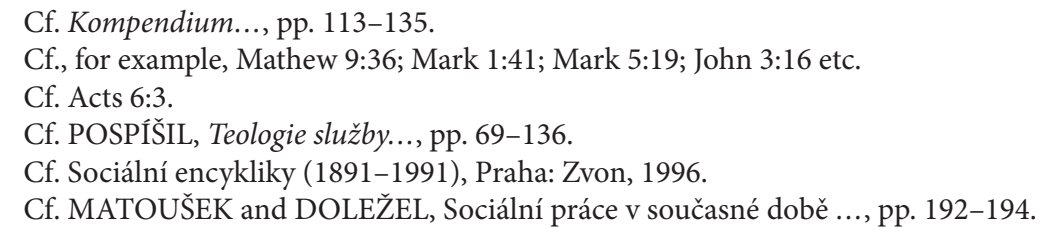


sociology, philosophy, law, medicine, etc.). It is based on a large number of theories and uses a wide range of different methods. ${ }^{31}$ In this paper, however, we do not want to deal with a specific area of social work but rather with a general view of the whole discipline. By its international definition, social work as such 'promotes social change, solving problems in interpersonal relationships and empowering and liberating people in order to fulfil their personal well-being. Using theories of human behaviour and social systems, social work intervenes where people come into contact with their environment. The principles of human rights and social justice are key to social work.'32 Social workers therefore try to help different groups of people in their difficult life situations. During the process of helping, social workers deal with the overall situation of man. They take into account not only social but also psychological, biological, or spiritual factors as human difficulties of a social nature may also arise from dimensions other than (only) the social. This aspect needs to be revealed in order to help people and solve the situation by a social worker or another specialist in the field, such as a psychologist. ${ }^{33}$

The above conception of the acts or works of mercy clearly shows that at the centre of attention is a person suffering from certain physical, mental, spiritual, and social deficiencies. As mentioned above, today's social work also looks at man in his entirety and sees him as a bio-psycho-sociospiritual unity. It strives to ensure that each of these areas and the needs arising from them will reach their fulfilment. Most of the aforementioned bodily needs are perhaps not surprising as they are so basic that their recognition and fulfilment are equally urgent at any time (when comparing Thomas' time and today). Food, drink, clothing, and dwellings simply belonged to the basic needs of the human being. They cannot be omitted and must always be fulfilled. ${ }^{34}$ Among other acts of physical mercy is a visit to the sick. Social workers who work with patients (whether in hospital or in other institutions) know that the available social support has a positive effect on the mental state of the patient and often leads to faster recovery. The need for social contact is one of the basic needs that cannot be neglected in the care of patients. ${ }^{35}$ The penultimate act of bodily mercy is the ransoming of captives. Today it may seem somewhat surprising but there were times when there were religious orders dedicated to the ransoming of prisoners (the Order of the Trinitarians or Mercedaries). ${ }^{36}$ Fortunately, the ransoming of prisoners is rarely needed, and nowadays it is no longer part of the normal activities of a social worker as the Ministry of Foreign Affairs and other state authorities are more involved. The inclusion of a funeral as one of the acts of physical mercy (which is the final act of love that we can give to a deceased person) may also be surprising. It has not only a physical but also a deep psycho-social dimension because it allows people around the deceased person to say goodbye to him and thus to handle the loss of this close person in a better way. Today, the public ceremony is becoming less common. Increasingly, we find that the meaning of a funeral is not well understood and appreciated. Therefore, the number of funerals without ceremony is increasing, that is, funerals where relatives do not wish to hold a public farewell to their loved ones. Although no statistics on funeral ceremonies are kept, according to Nešporovás research, a fifth of the population of the Czech Republic leans towards this type of funeral. It can be said that the failure to

31 Cf. ibid.

32 (c) International Federation of Social Workers: Global Definition of Social Work (on-line), available at: https://www.ifsw.org/what-issocial-work/global-definition-of-social-work/, cited $28^{\text {th }}$ December 2019.

33 Cf. (C) Poslání a cíle časopisu Sociální práce / Sociálna práca (on-line), available at: http://www.socialniprace.cz/index.php ?sekce $=1$ \&podsekce $=17$, cited $28^{\text {th }}$ December 2019.

34 As part of social services, meeting these needs is one of the basic activities that every residential service must guarantee. Cf. Act $108 / 2006$ Coll. $\$ 35$.

35 Cf. Jaro KŘIVOHLAVÝ, Psychologie zdraví, Praha: Portál, 2001, pp. 95-107.

36 Cf. POSPÍŠIL, Teologie služby..., pp. 111-112. 
organise a funeral ceremony in a time of peace and prosperity is a phenomenon absolutely unique and therefore worthy of reflection. The reasons for this behaviour will be diverse, ranging from financial to psychological or social. The living may perceive burial rites as too expensive, or too mentally burdensome for themselves. The form of funeral ceremonies, whether church or secular, is unsatisfactory for them. They do not perceive the funeral as a form of support for the living, which may be related to the widespread practice of rejecting condolences after a funeral ceremony. ${ }^{37}$ The question is what direction the development in this area will take. It is certainly not a major issue for social workers, but it still has its place. It is possible to contribute, at least in a small way, to the importance of this topic and the removal of its taboo.

If we proceed to the acts of mercy of the soul, the closest one to today's social worker is certainly advice or consolation. Counselling of various kinds is one of the important areas where a social worker can help..$^{38}$ Empathy, that is, the ability to recognise other people's emotions, is considered one of the most frequently mentioned abilities of social workers. It is also a necessary attribute if one wants to comfort others. To today's social worker, admonishment or the tolerance of the weaknesses of one's fellow men will be far more distant. Even here we would find parallels to today's social work. The acceptance of a client as he is, a non-evaluative attitude towards him, can also entail the ability to endure his weaknesses even if one uses different terms for such situations. The aim of the social worker is not to educate the client or to shape him according to the social worker's idea but to effectively help in his unique situation. And what about the admonition? Can a social worker still place this among the tools of his work today? Does it match with the abovementioned non-evaluation attitude? It can be assumed that even today it is possible to work with something like admonition. This may be a reminder of the consequences of a particular behaviour, or the indication of an unacceptable behaviour (either because it violates the law, or at least the rights of others). If we totally resigned from the activity of reminding about certain norms that the admonition presupposes, we would fall into total subjectivism and a relativism of values. This can be illustrated by the example of Nazi ideology where a social worker fully respecting the client and staying out of any assessment should also respect glaring injustice towards the mentally handicapped, Jews, etc. I consider this to be an absurd consequence of a consistently non-evaluation approach. It is necessary to evaluate and thus admonish but with respect to the client and to the persons associated with him and mutual actions. This avoids both ill-fated paternalism and the aforementioned absurd consequence of total value restraint.

\section{Charity and Philanthropic Approach}

After introducing Christian charity and its starting points for practical help to the neighbour (perhaps in the form of acts of mercy), and today's social work helping people who are in trouble in interpersonal relationships when fulfilling their own well-being, we can ask a question of whether these are different approaches or whether there is any similarity between them.

Looking at Musil's well-known typology of the concept of social work: administrative, professional, activist, and philanthropic, ${ }^{39}$ the Christian concept of charity is closest to the philanthropic concept. An administrative social worker is actually a prototype of an official who considers his main task the act of dealing with applications and who solves the situation of clients according to given regulations,

37 Cf. Olga NEŠPOROVÁ, O smrti a pohřbívání, Brno: CDK, 2013, pp. 203-212.

38 Basic social counselling is again obligatory equipment of every social service. Cf. Act 108/2006 Coll. $\$ 37$.

39 Cf. Libor MUSIL, Různost pojetí, nejasná nabídka a kontrola výkonu „sociální práce“, Sociální práce / Sociálna práca 2/2008, pp. 60-79. 
laws, or procedures. In addition, professionally understood social work emphasises that the worker is a specialist who focuses on a comprehensive assessment of the client's situation and, accordingly, chooses an intervention aimed at strengthening the client's abilities. In addition, an activist-oriented social worker plays the role of a 'partner' of the client. He treats clients as equals and helps them to face inequalities and discrimination. He teaches clients to defend their own interests. Philanthropic social work is then one that builds on the social worker / client relationship. Altruism, practical love of neighbour, and empathy are considered to be key elements in such social work. The social worker cooperates with other colleagues as well as with the client and his relatives to solve the client's problem. This concept does not mean that such a worker is also not a professional in his field. Rather, a deeply understood relationship to man based on the Christian (or at least Christian-inspired) conception of the human person and his unconditional dignity (which is not derived from any performance, merit, status, etc.) is emphasised. At the same time, some authors also see the risks of this approach. In particular, there is a certain tension between the worker's relationship to himself and the client. The realisation of this danger and its constant reflection in practice then helps the worker to use the relationship with the client as the basis for effective help. ${ }^{40}$ In practice, workers are not usually focused purely on one of the abovementioned types of social work. More often it is possible to find a combination of these.

In the Christian conception, every man is God's creation. He is a faithful image of his Creator. The relationship with God is an existential feature of every man. Among other things, it means rationality and freedom which makes man the only creature on earth who can act freely and therefore responsibly. He not only perceives himself to be the master of himself and thus acts in the world in this way, but also realises his dependence on creation and his transcendence. Man does not reach his completion in earthly life, he transcends it. ${ }^{41}$

As mentioned above, man is understood as a person. It includes both his unique and unrepeatable individuality and his inherently social dimension. Therefore, Christian charity overcomes the tension between focusing exclusively on the client as an individual and focusing on the client as part of society. Charity work admits the need for a personal relationship with one's neighbour which is its goal. At the same time, though, it is not an absolute goal and charity work is not absorbed by it. It is worth mentioning the subtle linguistic difference between philanthropic social work and Christian charity, which is quite inconspicuous at first glance. While the former uses the Greek word filia to express the personal relationship, the latter uses the Latin word caritas. Both mean love, but each time in a slightly different sense. Greek filia roughly corresponds to the general Latin word amor or amititia which means simple love, or more closely expresses love as friendship. The Latin word caritas, on the other hand, corresponds to the Greek word agape which is love. This love 'now becomes a true discovery of the other person and it overcomes the selfish personal focus which clearly prevailed before. Now love becomes the concern and care of the other. It is no longer a quest for oneself, immersion in the intoxication of happiness, because love now strives for the happiness of a beloved being. Love becomes a self-denial, it is ready for sacrifice. One is even looking for such love. ${ }^{32}$ Thus, Christian charity is very close to a philanthropic approach in social work but it should go beyond it and, in a sense, radicalise it with its concept of love for neighbour.

40 Cf. Michal OPATRNÝ, Etická dilemata vyplývající z odpovědnosti sociálních pracovníků k sobě samým a dilemata v nastavení hranic vůči klientům, Sešit sociální práce 4/2015, pp. 42-46.

41 Cf. SUTOR, Politická etika..., pp. 21-24.

42 BENEDIKT XVI., Deus caritas est, article art. 6. 


\section{Conclusion: Profession and Gift}

In conclusion, social work is a well-established profession today. However, it cannot be overlooked that one of the tools of social work is the social worker himself. It is therefore important that he not only has the appropriate knowledge and skills but also a mature personality. Not all that a social worker uses in his profession is knowledge gained by studying the relevant field. He also makes use of certain personal gifts which he received as a unique human person. On the one hand, it is what he gained from parents, loved ones, and society, and on the other, it is what he was given from God. Obviously, a social worker without religion will not have much understanding for 'something from above. Social work as a secular discipline, as we know it today, cannot count on the presence of such quality as well. However, this dimension of the social worker's personality cannot be ignored. There are a number of religious Christians among social workers, and they clearly exceed the proportion of Christians in society. Their motivation and personal equipment must take into account what is difficult to reflect upon within the secular discipline as they simply have it and live it in their experience and reflection of their work. It is primarily the domain of theology, and social work can reflect it in at least some kind of conditionality ('assuming X holds, $\mathrm{Y}$ can be deduced').

The Christian dimension of the social worker's personal equipment (consisting of the consciousness of 'having gifts from above') relates not only to faith but also to love which (together with faith and hope) forms the trinity of the divine or theological virtues. Unlike the ordinary rational or moral virtues which we obtain through repetitive action, these virtues are considered to be an undeserved gift of God which one cannot cause by oneself. One can accept them without resistance. Mercy, including the above described understanding of almsgiving, is thus not only one's own effort but it is the outcome of the gift of faith and love, that is, supernatural gifts that are accompanied by God's help for putting them into action.

To sum up, we can say that the difference between social work and charity is mainly motivation the Christian's motive is God and one's love for God (caritas). This love in turn manifests itself in concrete deeds of mercy towards the people we love because of God, thanks to God, and for these people themselves. This fulfils the main commandment which is to love God and neighbour. As has been shown, the fact that Christian love is seen as a gift from God is not an obstacle for its rational examination and reflection. It is clear from the example of Thomas Aquinas that even though love (caritas) is understood as something supernatural, it is not alien to man and it very well corresponds to the structure of the human person and his relationship with his neighbour. Whether this is the result of the wise creation of God, or merely the human wisdom of old Christian authors, let us leave it open. It is obvious that social work as a secular discipline and Christian theology open to God's transcendence is likely to vary here. However, this should not have any effect on the inspiration of the Christian reflection upon love for neighbour even for the secular social worker.

\section{Contact}

\section{Mgr. Helena Machulová, Ph.D.}

University of South Bohemia in České Budějovice

Faculty of Theology, Department of Lifelong Learning

Kněšská 8, 37001 České Budějovice

machulovah@tf.jcu.cz 